\title{
Species richness and diversity of aquatic insects inhabiting rice fields in Bogor, West Java, Indonesia
}

\author{
WAKHID $^{1, \bullet}$, AUNU RAUF ${ }^{2}$, MAJARIANA KRISANTI ${ }^{3}$, I MADE SUMERTAJAYA ${ }^{4}$, NINA MARYANA ${ }^{2}$ \\ ${ }^{1}$ Program of Entomology, Graduate School, Institut Pertanian Bogor. Jl. Lingkar Akademik, Kampus Dramaga, Bogor 16680, West Java, Indonesia \\ Tel.: +62-251-8622642, `email: wakhid.doank@yahoo.com \\ ${ }^{2}$ Department of Plant Protection, Faculty of Agriculture, Institut Pertanian Bogor. Jl. Kamper, Kampus Dramaga, Bogor 16680, West Java, Indonesia \\ ${ }^{3}$ Department of Aquatic Resources Management, Faculty of Fisheries and Marine Sciences, Institut Pertanian Bogor. Jl. Agatis, Kampus Dramaga, Bogor \\ 16680, West Java, Indonesia \\ ${ }^{4}$ Department of Statistics, Faculty of Mathematics and Natural Sciences, Institut Pertanian Bogor. Jl. Meranti, Kampus Dramaga, Bogor 16680, West \\ Java, Indonesia
}

Manuscript received: 2 October 2019. Revision accepted: 2 December 2019.

\begin{abstract}
Wakhid, Rauf A, Krisanti M, Sumertajaya IM, Maryana N. 2020. Species richness and diversity of aquatic insects inhabiting rice fields in Bogor, West Java, Indonesia. Biodiversitas 21: 34-42. Rice fields occupy the largest cultivated area in agricultural landscape in Indonesia and support a variety of living organisms, including aquatic insects. This study was conducted with the objective to determine the species richness and diversity of aquatic insects inhabiting rice fields. Sampling was made in March, May, and July 2017 in rice fields at Situgede, Pandansari, and Kawungluwuk (Bogor region, West Java, Indonesia), and carried out by dragging dip net on the bottom along the edge of the rice plots. A total of 3,306 individuals representing 45 species of aquatic insects belonging to 30 genera, 20 families, and seven orders were recorded. Order Hemiptera was the most abundance comprising $28.89 \%$ of the total insects collected, followed by Diptera (24.80\%), Coleoptera (24.41\%), and Odonata (21.42\%). Functional feeding group analysis showed that collectors-gatherers had the highest proportion $(40-46 \%)$, followed by predators $(23-44 \%)$ and scrapers $(10-35 \%)$. Rank-abundance curve showed low species evenness with the four most abundant species were Micronecta siva (Kirkaldy) (Hemiptera: Micronectidae), Chironomus sp. (Diptera: Chironomidae), Orthetrum sabina (Drury) (Odonata: Libellulidae), and Helochares sp. (Coleoptera: Hydrophilidae). The Shannon-Wiener index showed the lowest value $\left(\mathrm{H}^{\prime}=1.84\right)$ at Situgede and the highest $\left(\mathrm{H}^{\prime}=2.05\right)$ at Pandansari. Richness estimate and individual-based rarefaction curve revealed that rice fields at Pandansari have more species richness than the other two sites. This study provides some insights into the aquatic insect community of the human-made ecosystem and suggests that the ecological approach to pest management is necessary for maintaining ecosystem health and promoting biodiversity.
\end{abstract}

Keywords: Aquatic insects, biodiversity, Bogor, rice fields

\section{INTRODUCTION}

Rice is the most important food crop in Indonesia, with 9.54 million hectares harvested during January-September 2018 (BPS 2019). Rice fields commonly occupy the largest cultivated area among agricultural land and form an ecosystem representing a major semi-natural environment (Ueno 2012). Rice fields provide habitats for many organisms that constitute a community, which contains a wide variety of species that differ in their functions and represent biological diversity in agricultural lands (Kiritani 2000). Therefore, rice fields support, at least in part, biodiversity in the area or region. Recently, biodiversity in rice fields has received growing attention because it plays a significant role in ecosystem services (Luo et al. 2014; Settele et al. 2019). For example, rice fields are the habitats for diverse parasitoids and arthropod predators, which are important natural enemies of rice pests. Unfortunately, rice cultivation has been heavily dependent on continuous and excessive inputs of chemical pesticides, which causes the loss of biodiversity of such beneficial organisms and leads to the resurgence of pests (Way and Heong 1994; Katayama et al. 2014).
Integrated pest management (IPM) is an ecological approach for the control of agricultural pests. An important principle of IPM is to maximize natural control. Therefore, the knowledge of arthropod abundance, diversity, species richness, and community structure are important considerations in designing pest management strategies (Zhang et al. 2013). Rice fields incorporate both terrestrial and aquatic components and often support a high level of biodiversity, which plays an important role in agricultural productivity (Schoelny et al. 1998). The maintenance of invertebrate biodiversity within agricultural environments can enhance some important agronomical processes, such as nutrient cycling and biological pest control (Wilson et al. 2007). However, most of the biodiversity studies in rice fields focused on terrestrial insects, whether they are pests or natural enemies (Heong et al. 2009; Schoelny et al. 1998; Jauharlina et al. 2019). Less attention has been paid to elements of the aquatic fauna in rice fields due to no direct economic impact on rice production (Kiritani 2000).

Aquatic insects play an important role in aquatic ecosystem functioning (Dunbar et al. 2010). Some of the insect pest natural enemies in rice fields are associated with water, such as aquatic insects of family Mesoveliidae and Veliidae have been reported to prey on brown planthopper 
(Heong et al. 2009). Species such as chironomids that are neither pests nor natural enemies, are useful as an alternative food of generalist predators (Settle et al. 1996). Immigration of spiders to rice fields occurs after the appearance of chironomids (Way and Heong 1994). When chironomids are abundant, the density of spiders increases correspondingly, and they act as biological control agents against planthoppers and leafhoppers (Hidaka 1990). Insect communities are important factors for check and balance in the rice field, thereby controlling the increase in insect populations. Park and Lee (2006) provided isotopic evidence that filter feeders and detritivores such as those in the families Chironomidae and Entomobryidae play an important role in sustaining predators such as spiders in rice ecosystems. Kiritani (2000) proposed an Integrated Biodiversity Management (IBM) to include conservation towards such kind of insects.

Until recently, there have been only a few studies on the aquatic insects in rice fields have been conducted in Indonesia (e.g., Salmah et al. 2017). Taking into account the importance of aquatic insects in rice fields, the present study was undertaken to determine the species richness and diversity of aquatic insects inhabiting rice fields.

\section{MATERIALS AND METHODS}

\section{Study site}

The study was carried out in rice fields located at three sites having different elevations i.e., Kawungluwuk (highland), Pandansari (midland), and Situgede (lowland). Situgede (S 6³2'58.72"; E 106 44'31.84") and Pandansari (S 6³8'32.00"; E 106 50'50.10") administratively belong to District of Bogor, West Java, Indonesia while Kawungluwuk (S 643'44.50"; E 107²'21.40") belongs to
District of Cianjur, West Java, Indonesia (Figure 1). The coordinates and altitude of each site were recorded using a handheld GPS (Garmin GPSmap 62s). Due to the water availability year-round, rice was planted continuously every season. Rice varieties grown by farmers in all sites were mostly Ciherang and Inpari, while fertilizers used were Urea and NPK, and pesticides were carbofuran, cyhalothrin, deltamethrin, methomyl, and profenofos.

\section{Insect sampling and measurement of water physicochemical properties}

In each location, four adjacent rice plots (every $2000 \mathrm{~m}^{2}$ in size) with a similar plant age were selected. Our preliminary samplings indicated that various aquatic insects were found more at the edges of the rice plot, certainly due to having more volume of water. Therefore, sampling was done on this part of the rice plot. Samples were taken along $5 \mathrm{~m}$ of each of four edges for every rice plot. Collections of aquatic insects in each plot were made by dragging a dip net on the bottom over a distance of $5 \mathrm{~m}$ along the edge of each rice plot. Samplings of aquatic insects were conducted between 8.00 am to 15.00 pm every two months i.e., March, May, and July 2017, during rice cultivation periods. On each of the three sampling occasions (March, May, July), a total of 16 samples were collected at each site. Insects caught in the net were then collected and placed in vials containing $96 \%$ alcohol for preservation, since the aquatic insects have high water content. Insects were identified up to the lowest taxonomic category following the standard keys (Morse et al. 1994; Cheng et al. 2001; Nieser 2004; Yang and Zettel 2005; Polhemus and Polhemus 2013). Some of the species which could not be identified were included as unidentified and given numerics for the purpose of quantitative analysis.
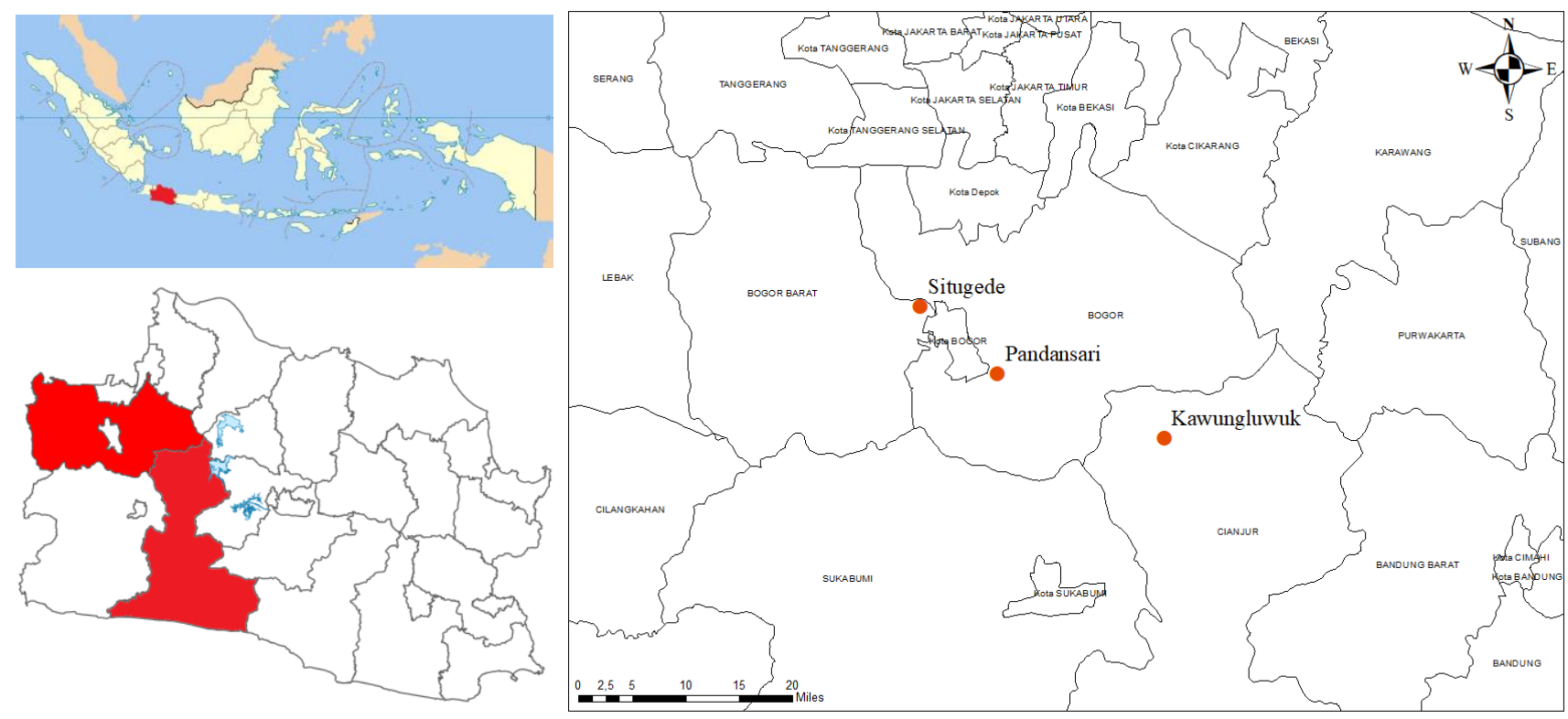

Figure 1. Map of Bogor area showing location of sampling sites (marked with red dot) (drawn using Arc GIS version 10.41) 
Selected physicochemical properties of rice field water including temperature, $\mathrm{pH}$, and dissolved oxygen (DO) were recorded directly at the sampling sites. Water temperature and $\mathrm{pH}$ were measured using thermo- $\mathrm{pH}$ meter (ADWA AD-12), while DO was measured using DO meter (Lutron 5510).

\section{Data analysis}

The aquatic insect abundance and taxonomic richness were tabulated for each site. Mapping of sampling location in three rice fields performed using Arc GIS version 10.41. The Kruskal-Wallis test was used to compare composition among the sites. The specimens collected were assigned to different functional feeding groups (FFG) following Merritt and Cummins (1996) and Ramirez and Gutierrez-Fonseca (2014). Species recorded in this study were pooled and ranked on the basis of the relative abundance of individual species. The relationship between the most predominant species and environmental variables was examined using the Pearson correlation. The diversity index of ShannonWiener $\left(\mathrm{H}^{\prime}=-\sum\right.$ pi.lnpi), an evenness index of Pielou $\left(\mathrm{J}=\mathrm{H}^{\prime} / \ln \mathrm{S}\right)$ were used to assess insect diversity within sites (Magurran 2004). Significant differences in species diversity and evenness indices among the sites were determined using the pair-wise permutation test in the program PAST 3.0 (Hammer et al. 2001). First order Chao (Chao 1) species richness estimate was used to determine the expected number of species. Sampling completeness was calculated as the ratio of observed species richness to the species richness estimate value and expressed as a percentage. Individual-based rarefaction curves, with 100 randomizations, were used to generate the species accumulation curve of species richness for each site.

\section{RESULTS AND DISCUSSION}

\section{Physico-chemical properties}

The means of $\mathrm{pH}$ of water showed little variation among sites, with the lowest (7.53) at Pandansari and the highest (7.88) at Situgede (Table 1). The lowest water temperature was found at Kawungluwuk $\left(25.63^{\circ} \mathrm{C}\right)$, followed by Pandansari $\left(27.10^{\circ} \mathrm{C}\right)$, and the highest was at Situgede $\left(32.20^{\circ} \mathrm{C}\right)$. These differences in temperature were related to elevation. Kawungluwuk is located in the highland (830 $\mathrm{m}$ above sea level), while Pandansari in the midland (400 m), and Situgede in the lowland $(170 \mathrm{~m})$. The dissolved oxygen (DO) varied slightly, ranging from 4.13 $\mathrm{mg} / \mathrm{L}$ (Pandansari) up to $5.28 \mathrm{mg} / \mathrm{L}$ (Kawungluwuk).

\section{Aquatic insect fauna}

A total of 3,306 individuals representing 45 species belonging to 30 genera, 20 families and 7 orders were recorded in this study (Table 2). The highest number of species and individuals of aquatic insects was recorded at Pandansari, with 36 species and 1,153 individuals and the lowest was recorded at Kawungluwuk with 18 species and 473 individuals. Rice fields at Situgede were represented by 28 species and 1,680 individuals. Among the three sites, rice fields at Kawungluwuk and Pandansari showed a significant difference (Kruskal-Wallis test: $\mathrm{H}=7.66, \mathrm{P}=$ 0.004) in terms of species composition, but no significant difference with Situgede $(\mathrm{H}=2.54, \mathrm{P}=0.08)$, and between Pandansari and Situgede $(\mathrm{H}=1.32, \mathrm{P}=0.24)$. Rice fields are an ecosystem with high biological diversity compared to other agricultural areas (Stenert et al. 2012). Many aquatic insects like hemipterans, coleopterans, and dipterans are known to reproduce in rice fields. Ponraman et al. (2016) reported 35 insect species belonging to five orders were collected from rice fields in India. A similar number of species was observed in rice fields in North Sumatera (Salmah et al. 2017). Thongphak and Iwai (2016) reported 17 insect species belong to 16 families and six orders in Thailand. Species richness will be underestimated if specimens are identified only to morphospecies because, at this level, genera may contain more than one species (Rosenberg et al. 2008). For our study, only nine taxa were identified to the species level, 30 to generic level, and the remaining nine to family level (Table 2). Unique taxa may be undetected at the generic level or higher (McPherson et al. 2013). Therefore, the observed taxa richness may have been underestimated.

The percentage composition of various insect orders based on the abundance and number of species is presented in Figure 2. Among the aquatic insect fauna inhabiting rice fields, the order Hemiptera was the most abundant comprising $28.89 \%$ of the total insects collected, followed by Diptera $(24.80 \%)$, Coleoptera $(24.41 \%)$, and Odonata $(21.42 \%)$ (Figure 2.A). The three other orders (Collembola, Ephemeroptera, Trichoptera) represented less than 1\%. The order Hemiptera was represented by eight families, with the most abundant was the member of family Micronectidae (894 individuals) or $93.6 \%$ of the total hemipteran. The order Diptera was contributed by five families representing Ceratopogonidae, Chironomidae, Culicidae, Syrphidae, and Tabanidae. Of these, Chironomidae was the most common family among Diptera in all rice fields sampled, as also occurred in rice fields in North Sumatera (Salmah et al. 2017).

Table 1. Physico-chemical properties of rice fields at three sites

\begin{tabular}{lccc}
\hline \multirow{2}{*}{ Characteristics } & \multicolumn{3}{c}{ Rice fields at } \\
\cline { 2 - 4 } & Kawungluwuk & Pandansari & Situgede \\
\hline Altitude $(\mathrm{m})$ & 830 & 400 & 170 \\
Water $\mathrm{pH}$ & $7.81 \pm 0.26^{*}$ & $7.53 \pm 0.05$ & $7.88 \pm 0.12$ \\
Water temperature $\left({ }^{\circ} \mathrm{C}\right)$ & $25.63 \pm 1.44$ & $27.10 \pm 0.22$ & $32.20 \pm 1.50$ \\
Dissolved oxygen $(\mathrm{mg} / \mathrm{L})$ & $5.28 \pm 1.01$ & $4.13 \pm 0.05$ & $5.23 \pm 0.83$ \\
\hline
\end{tabular}


Table 2. Aquatic insects found in rice fields at three sites

\begin{tabular}{|c|c|c|c|c|c|}
\hline \multirow{2}{*}{ Taxon } & \multirow{2}{*}{ FFG* } & \multicolumn{3}{|c|}{ Rice fields at } & \multirow{2}{*}{ Total } \\
\hline & & Kawungluwuk & Pandansari & Situgede & \\
\hline \multicolumn{6}{|l|}{ Coleoptera } \\
\hline \multicolumn{6}{|l|}{ Dytiscidae } \\
\hline Cybister sp. & $\operatorname{Pr}$ & - & - & 9 & 9 \\
\hline Dytiscidae sp. 1 & $\operatorname{Pr}$ & - & - & 1 & 1 \\
\hline Dytiscidae sp. 2 & $\operatorname{Pr}$ & - & - & 2 & 2 \\
\hline Eretes $\mathrm{sp}$. & $\operatorname{Pr}$ & - & 9 & 5 & 14 \\
\hline Hyphydrus sp. & $\operatorname{Pr}$ & 1 & 12 & 5 & 18 \\
\hline Laccophilus sp. 1 & $\operatorname{Pr}$ & - & 4 & 38 & 42 \\
\hline Laccophilus sp. 3 & $\operatorname{Pr}$ & 1 & 10 & - & 11 \\
\hline Laccophilus sp.5 & $\operatorname{Pr}$ & - & 5 & 29 & 34 \\
\hline Laccophilus sp.6 & $\operatorname{Pr}$ & - & 8 & - & 8 \\
\hline \multicolumn{6}{|l|}{ Hydrophilidae } \\
\hline Berosus sp. & $\mathrm{CG}$ & 1 & 1 & - & 2 \\
\hline Helochares sp. & CG & 49 & 125 & 425 & 599 \\
\hline Hydrophilidae sp.1 & CG & - & 6 & 12 & 18 \\
\hline Hydrophilidae sp.2 & CG & - & 2 & - & 2 \\
\hline Hydrophilidae sp.3 & $\mathrm{CG}$ & - & 1 & - & 1 \\
\hline Hydrophilidae sp.5 & $\mathrm{CG}$ & - & 29 & - & 29 \\
\hline Hydrophilus sp.1 & CG & - & 1 & - & 1 \\
\hline Hydrophilus sp.2 & CG & - & 5 & 11 & 16 \\
\hline \multicolumn{6}{|l|}{ Collembola } \\
\hline Isotomidae & & & & & \\
\hline Isotomidae sp. & CG & 7 & 3 & - & 10 \\
\hline Diptera & & & & & \\
\hline Ceratopogonidae & & & & & \\
\hline Bezzia sp. & $\operatorname{Pr}$ & 9 & - & 10 & 19 \\
\hline Chironomidae & & & & & \\
\hline Chironomus sp. & CG & 165 & 291 & 223 & 679 \\
\hline Procladius sp. & $\operatorname{Pr}$ & 5 & ret & 2 & 7 \\
\hline Culicidae & & & & & \\
\hline Anopheles sp. & $\mathrm{CF}$ & - & 16 & 2 & 18 \\
\hline Culex sp. & $\mathrm{CF}$ & - & 6 & 4 & 10 \\
\hline Syrphidae & & & & & \\
\hline Eristalis sp. & CG & - & - & 1 & 1 \\
\hline Syrphidae sp. & CG & - & 2 & & 2 \\
\hline Tabanidae & & & & & \\
\hline Chrysops sp. & $\operatorname{Pr}$ & - & 2 & 3 & 5 \\
\hline Tabanus sp. & $\operatorname{Pr}$ & 68 & 5 & 6 & 79 \\
\hline Ephemeroptera & & & & & \\
\hline Baetidae & & & & & \\
\hline Platybaetis sp. & $\mathrm{CG}, \mathrm{Sc}$ & 2 & 1 & 2 & 5 \\
\hline Hemiptera & & & & & \\
\hline Belostomatidae & & & & & \\
\hline Diplonychus rusticus (Fabricius) & $\operatorname{Pr}$ & 9 & 5 & - & 14 \\
\hline Gerridae & & & & & \\
\hline Limnogonus fossarum (Fabricius) & $\operatorname{Pr}$ & - & 12 & - & 12 \\
\hline Ptilomera tigrina Uhler & $\operatorname{Pr}$ & 5 & 1 & - & 6 \\
\hline Hydrometridae & & & & & \\
\hline Hydrometra sp. & $\operatorname{Pr}$ & - & 2 & - & 2 \\
\hline Mesovellidae & & & & & \\
\hline Mesovelia sp.1 & $\operatorname{Pr}$ & 3 & - & 7 & 10 \\
\hline Mesovelia sp.2 & $\operatorname{Pr}$ & - & 1 & - & 1 \\
\hline Micronectidae & & & & & \\
\hline Micronecta ludibunda Breddin & Sc & 11 & 12 & 2 & 25 \\
\hline Micronecta siva (Kirkaldy) & Sc & 27 & 389 & 453 & 869 \\
\hline Nepidae & & & & & \\
\hline Laccotrephes sp. & $\operatorname{Pr}$ & - & - & 1 & 1 \\
\hline Notonectidae & & & & & \\
\hline Anisops bouvieri Kirkaldy & $\operatorname{Pr}$ & - & 3 & 2 & 5 \\
\hline Veliidae & & & & & \\
\hline Rhagovelia sp. & $\operatorname{Pr}$ & 9 & 1 & - & 10 \\
\hline Odonata & & & & & \\
\hline Coenagrionidae & & & & & \\
\hline Agriocnemis sp. & $\operatorname{Pr}$ & 16 & 3 & 3 & 22 \\
\hline Pseudagrion sp. & $\operatorname{Pr}$ & - & - & 1 & 1 \\
\hline Libellulidae & & & & & \\
\hline Acisoma panorpoides (Rambur) & $\operatorname{Pr}$ & - & 3 & - & 3 \\
\hline Orthetrum sabina (Drury) & $\operatorname{Pr}$ & 85 & 142 & 396 & 623 \\
\hline Pantala flavescens (Fabricius) & $\operatorname{Pr}$ & - & 34 & 25 & 59 \\
\hline Trichoptera & & & & & \\
\hline Hydropsychidae & & & & & \\
\hline Hydropsychidae sp. & $\mathrm{CF}$ & - & 1 & - & 1 \\
\hline Number of individuals $(\mathrm{N})$ : & & 473 & 1,153 & 1,680 & 3,306 \\
\hline Number of species $(\mathrm{S})$ : & & 18 & 36 & 28 & 45 \\
\hline
\end{tabular}


The order Coleoptera was represented by families Dytiscidae and Hydrophilidae with a total of 17 morphospecies. The order Odonata was represented by the families Coenagrionidae and Libellulidae. The order Collembola, Ephemeroptera, and Trichoptera, each represented by only one family. However, in terms of the species number, insects belonging to order Coleoptera showed a higher number of species $(37.78 \%)$ followed by Hemiptera (24.44\%), Diptera 20.0\%), and Odonata $(11.11 \%)$ (Figure 2B). Higher species richness of Coleoptera was also reported from rice fields in Argentina (Lutz et al. 2015). Orders Collembola, Ephemeroptera, and Trichoptera each represented by one species or about $6.7 \%$ altogether. The low abundance of Ephemeroptera and Trichoptera and the absence of Plecoptera in rice fields are expected since they are sensitive to organic pollution. They live mainly in clean and well-oxygenated waters (Rosenberg et al. 2008). However, Salmah et al. (2017) reported a high proportion $(27.97 \%)$ of mayflies (Ephemeroptera: Baetidae) in rice fields in North Sumatera, and so Thongphak and Iwai (2016) in Thailand.

The analysis of functional feeding group (FFG) is presented in Figure 3. For taxa belonging to more than one group, only the main feeding behavior was considered. This study showed a higher proportion of collectorgatherers, ranged from $40.36 \%$ at Situgede to $45.88 \%$ at Kawungluwuk (Figure 3). Collector-gatherers were dominated by Hydrophilidae and Chironomidae. Chironomids play an important role in the food webs of aquatic communities, representing a major link between producers and secondary consumers (Tokeshi 1995). Chironomid larvae exhibit generalist and opportunistic feeding habits, i.e., feeding on what was available at that moment. Based on gut analysis, the larvae ingest five kinds of food items: algae, detritus and associated microorganisms, debris, and invertebrates (Naser and Roy 2012). A higher proportion of predators was also found at Kawungluwuk (44.61\%) followed by Situgede $(32.44 \%)$ and Pandansari $(22.72 \%)$. The predators were dominated by the family Dytiscidae (Coleoptera) and the family Libellulidae (Odonata). Scrapers were higher $(35.04 \%)$ at Pandansari as compared to Situgede (27.08\%), and Kawungluwuk $(9.51 \%)$. In this study, scrapers were represented by Micronecta spp. The mouthparts indicate that they are capable of ingesting and digesting solid food, in contrast with the rest of Hemiptera, which only can consume liquid food (Hadicke et al. 2017). It has been reported that Micronecta spp. feed on detritus and algae (Fernando and Leong 1963). Collector-filterers were scarce and comprised less than $2 \%$ of the total insects collected, and they were represented by the larvae of Hydropsychidae (Trichoptera) and Culicidae (Diptera).

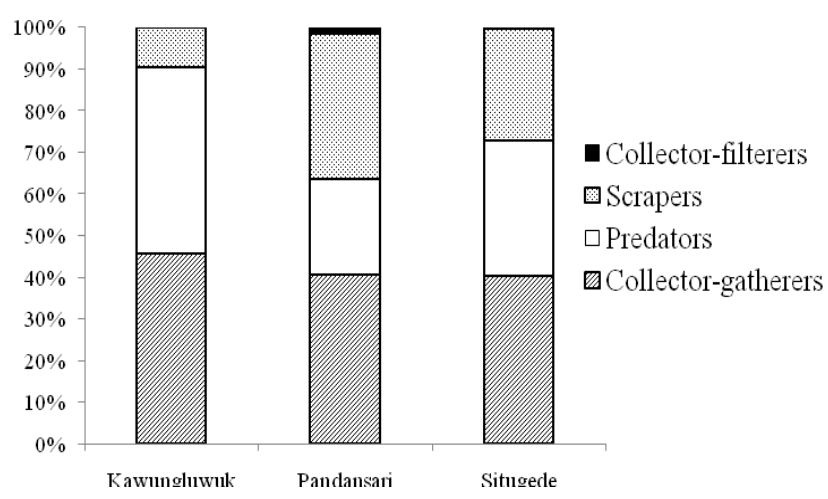

Figure 3. Relative abundance of aquatic insects among functional feeding groups in rice fields at three sites

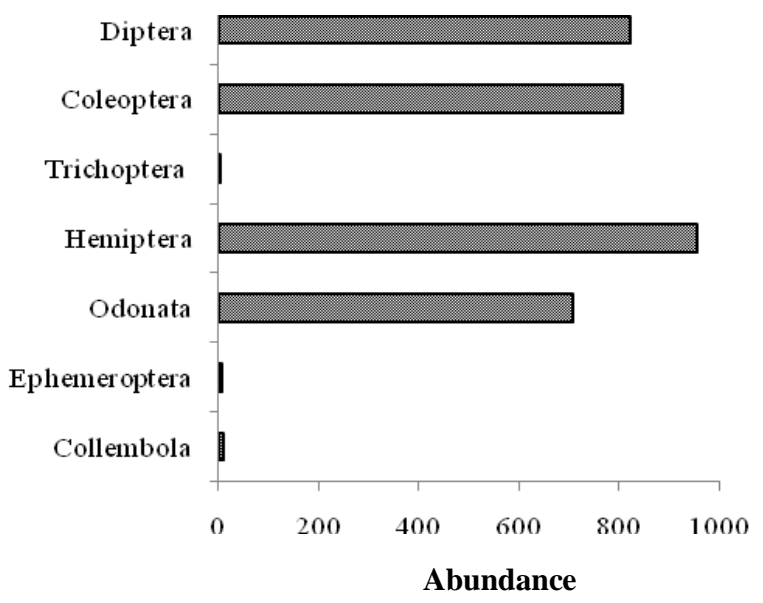

A

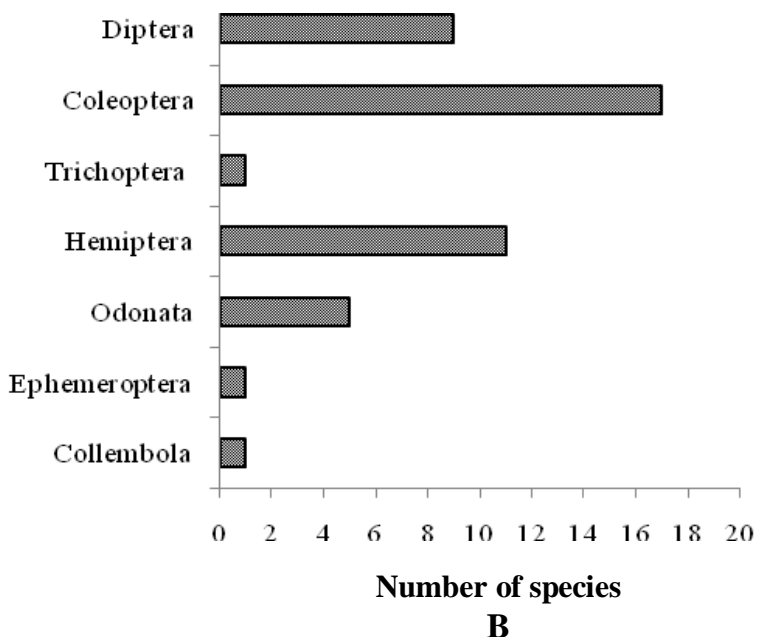

Figure 2. Composition of aquatic insect orders according to abundance (A) and number of species (B) 


\section{Species ranking}

The overall ranking of 45 aquatic insect species according to their relative abundance showed that $M$. siva, Chironomus sp., O. sabina, and Helochares sp. occupied ranks 1,2,3, and 4 , respectively, having a relative abundance of $26.28 \%, 20.53 \%, 18.85 \%$, and $18.12 \%$, respectively (Figure 4). The next four species are ranked between 5 and 8 with an abundance range of $1.0 \%$ to $2.4 \%$, and they together accounted for $6.47 \%$ of total abundance. The remaining 37 species are ranked between 9 and 45 and they together accounted for $9.71 \%$ of total abundance (Table 2; Figure 4). The steepness of the curve indicates low species evenness. High abundance of $M$. siva, Chironomus sp., O. sabina, and Helochares sp. is in accordance with the previous reports, as will be discussed in the following paragraphs.

The high abundance of Micronecta spp. has also been reported from rice fields in Philippine (Schoenly et al. 1998) and Thailand (Thongphak and Iwai 2016). The genus of Micronecta has been reported to inhabit inundated aquatic habitats or close to stagnant waters (Nieser et al. 2005). Yano et al. (1981) reported 18 species of Micronecta associated with rice fields in Asia, with Micronecta quadristrigata Breddin as the most widely distributed and common species of the Corixidae in Southeast Asian aquatic habitats. The abundance of $M$. siva was negatively correlated with the altitude $(\mathrm{r}=-0.701, \mathrm{P}$ $=0.011$ ). Several species of Corixoidea benefit from their role as pioneer species in quickly colonizing new habitats, including newly planted rice fields (Savage 1989).

Chironomid larvae are one of the most ubiquitous and usually the most common insect found in all types of freshwater ecosystems (Nicacio and Juen 2015). Chironomus is an important component that connects different trophic levels and plays an important role in the recycling of organic matter. Chironomus spp has been reported as a dominant larval chironomid genus in rice fields in various states/countries e.g., in California (Hesler et al. 1993), Mexico (Mercer et al. 2016), and Brazil (Wandscheer et al. 2017). A significant abundance of Chironomidae is associated with the fact that such insects are considered resistant to the environmental conditions of oxygen depletion and disturbances associated with rice crop management (Molozzi et al. 2007). Moreover, they are detritivores that feed on organic matter deposited in the sediment, which favors their adaptation to several environments (Wandscheer et al. 2017).

Orthetrum sabina was one of the dominant species found in rice fields, especially at Situgede and Pandansari. A similar result was reported by Salmah et al. (2017) who conducted their study in North Sumatera. Kandibane et al.
(2007) also reported $O$. sabina as one of the most abundant dragonflies in rice fields in Tamil Nadu, India. Rice fields provide a suitable habitat for dragonfly oviposition (Corbet 1980). Family Libellulidae as always found to be the most dominant group of dragonflies because of its adaptation and tolerable to various environments, even to the extreme environment such as habitat with low dissolved oxygen or highly eutrophic environments (Clausnitzer 2003). Our study found that the abundance of $O$. sabina was negatively correlated with altitude $(\mathrm{r}=-0.711, \mathrm{P}=0.01)$.

Helochares sp. is commonly found in flooded aquatic habitats such as ponds, lakes, water banks, and riverbank (Fenglong and Tang 2018). Yano et al. (1983) reported Helochares anchoralis (Sharp) as the common species inhabiting rice fields, they are widely distributed in the Oriental region, including Java and Sumatera. Abundance of Helochares sp. was positively correlated with water temperature $(\mathrm{r}=0.852, \mathrm{P}<0.001)$, but negatively correlated with altitude $(\mathrm{r}=-0.759, \mathrm{P}=0.004)$.

\section{Estimates of species richness and diversity}

Estimation of species richness in the three rice fields by Chao 1 showed that expected species richness for Kawungluwuk and Situgede (Table 3) are very close to their observed values (Table 2), with sampling completeness were $92.30 \%$ and $97.02 \%$, respectively. The estimate of species richness for Pandansari (42) was higher by six species than the observed value (36), or sampling completeness was about $86 \%$. The Chao1 estimator is calculated using taxa represented by singletons or doubleton specimens (Colwell and Coddington 1994). As the number of singletons increases relative to doubletons, the estimate increases in value (Chazdon et al. 1998). Individual-based rarefaction curves from the three rice fields showed a quick rise at first and then leveled off (Figure 5).

The Shannon-Wiener diversity index of Kawungluwuk $\left(\mathrm{H}^{\prime}=2.03\right)$ and Pandansari $\left(\mathrm{H}^{\prime}=2.05\right)$ each significantly $(\mathrm{P}=$ 0.001 and $\mathrm{P}=0.004$, respectively) were higher than those of Situgede $\left(H^{\prime}=1.84\right)$ (Table 3$)$. These differences among rice fields may be related to changes in species richness, evenness, or both. An increase in species richness and evenness will cause $H^{\prime}$ to increase. Rice fields at Pandansari and Situgede have similar values of evenness $\left(\mathrm{J}=0.57\right.$ and $\mathrm{J}=0.55$, respectively), and this difference in $\mathrm{H}^{\prime}$ values between the two rice fields was due to higher species richness at Pandansari $(\mathrm{S}=36)$ than at Situgede $(S=28)$. In contrast, rice fields at Kawungluwuk have the lowest richness $(\mathrm{S}=18)$ but have significantly $(\mathrm{P}=0.001)$ higher evenness $(\mathrm{J}=0.70)$, and this contributes to a relatively high H' value. The diversity of aquatic insects in rice fields can be affected by agronomic practices.

Table 3. Species richness and diversity parameters of aquatic insects in rice fields at three sites

\begin{tabular}{lccc}
\hline \multirow{2}{*}{ Richness/diversity } & \multicolumn{3}{c}{ Rice fields at } \\
\cline { 2 - 4 } & Kawungluwuk & Pandansari & Situgede \\
\hline Estimated species richness (Chao 1) & 19.5 & 41.6 & 28.86 \\
(Bootstrap 95\% confidence interval) & $(15-21)$ & $(29.50-46.0)$ & $(23.25-35.33)$ \\
Shannon-Wiener diversity index(H')* & $2.03^{\mathrm{a}}$ & $2.05^{\mathrm{a}}$ & $1.84^{\mathrm{b}}$ \\
Pielou evenness index (J)* & $0.70^{\mathrm{a}}$ & $0.57^{\mathrm{b}}$ & $0.55^{\mathrm{b}}$ \\
\hline
\end{tabular}

*Significant differences were determined according to pair-wise permutation test in PAST 3.0 


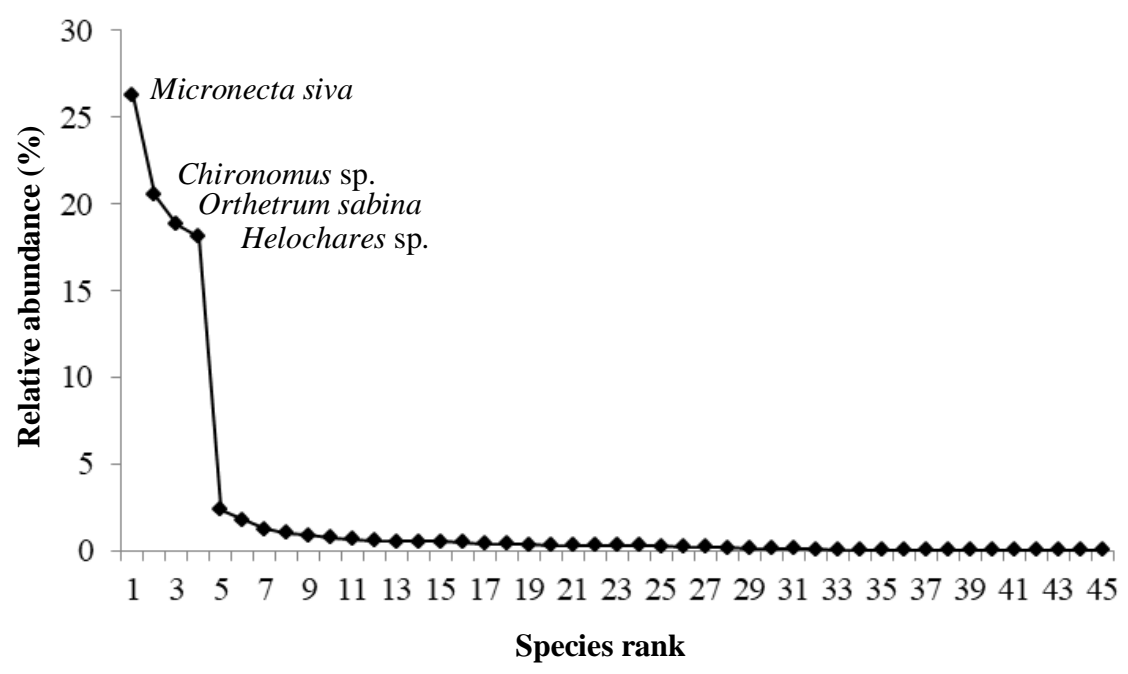

Figure 4. Rank-abundance curve of aquatic insects inhabiting rice fields (all sites pooled together; names of four most abundant species)

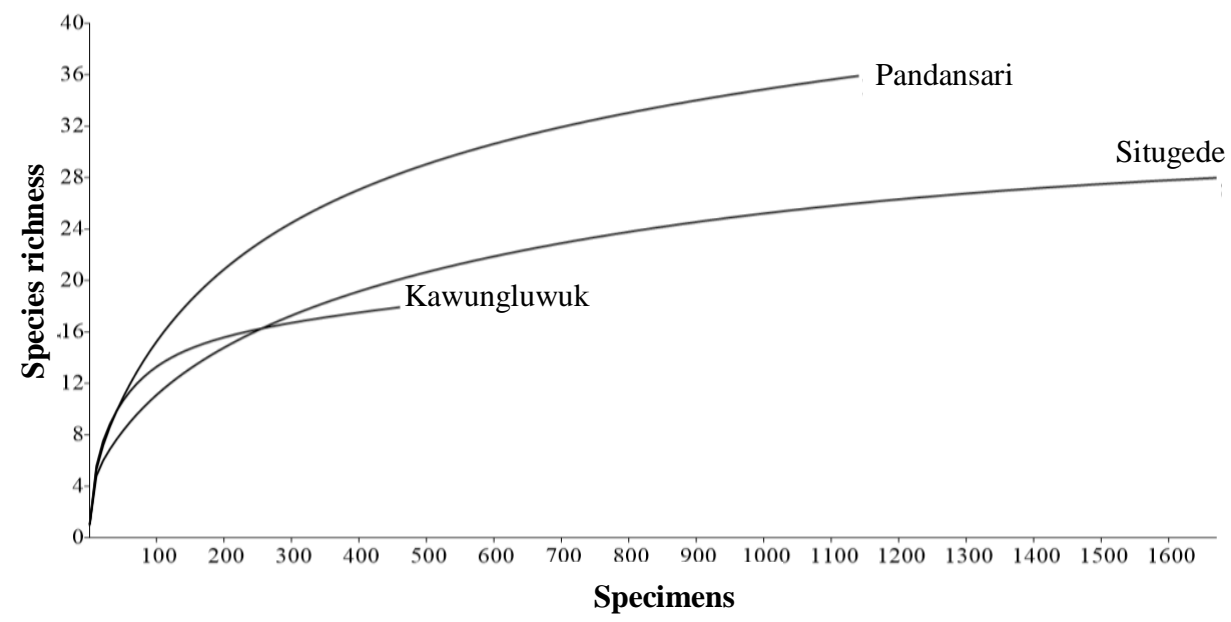

Figure 5. Individual-based rarefaction curve of aquatic insect species in rice fields recorded from three sites

Thongphak and Iwai (2016) found the Shannon-Wiener index of aquatic insects in organic rice fields in Thailand averaged 2.02, whereas in conventional rice fields 1.92 . Wilson et al. (2007) also reported greater biodiversity existed within aquatic macroinvertebrate communities of rice fields that developed under organic management regimes than under conventional regimes in Australia. The biodiversity in rice fields also depends on the quantitative status of water as well as physicochemical properties. The abundance of aquatic macroinvertebrates generally increases with water permanence, as more species can complete their life cycles. Therefore, the length of the flooded period has special importance in structuring rice field macroinvertebrates (Stenert et al. 2018).

\section{Implication for IPM and conservation}

Rice fields are human-made ecosystems with high biodiversity of aquatic macroinvertebrates (Stenert et al. 2012). One of the most abundant aquatic insects in the rice fields is chironomids. They can function as an alternative food source for generalist predators such as spiders (Settle et al. 1996). Abundance of chironomids is generally followed by the increase of spider density, which in turn acts as biological control agents against planthoppers and leafhoppers. Therefore, the presence of filter feeders and detritivores such as those in the family Chironomidae play an important role in sustaining predators such as spiders in rice ecosystems. Settle et al. (1996) reported that detrital subsidies to rice fields had been found to initiate trophic cascades in which primary producer populations are increased, leading to increases in predator numbers and reduction in primary consumers from the larger predator population. Generating this cascade, especially in the early growing season in rice fields, has been found to reduce the number of insect pests in rice fields. Biological control via detrital subsidies can reduce the need for pesticide applications that negatively affect wetland biota (Mercer et 
al. 2016). This condition is important in understanding and developing ecologically-based IPM for rice.

Although rice fields lack the structural and floristic diversity of natural wetlands, they can be important for conservation initiatives, particularly in areas where natural wetlands have declined. Flooded rice fields can provide habitats for wetland species and ecosystem services similar to those of natural wetlands (Katayama et al. 2014). Rice fields are temporary wetlands that harbor many of the same species that breed in temporary natural ponds. In this regard, rice fields have been recognized as having considerable conservation value for many aquatic species, including macroinvertebrates (Maltchik et al. 2017). Two insect species i.e., Lethocerus deyrollei Vuillefroy (Hemiptera: Belastomatidae) and Cybister tripunctatus orientalis Gschwendtner (Coleoptera: Dytiscidae) have been listed on the red data list book as endangered species inhabiting rice fields in Japan (Hidaka 1988). The rice agroecosystem has the potential to help sustain regional biodiversity and ecosystem services. Therefore, environmentally sound rice production and ecological sustainability can be achieved by restoring rice field biodiversity, including aquatic insects.

In conclusion, the rice fields in the Bogor area were inhabited by at least 45 species of aquatic insects representing 30 genera, 20 families and seven orders. The four most common species found were Micronecta siva (Hemiptera: Micronectidae), Chironomus sp. (Diptera: Chironomidae). Orthetrum sabina (Odonata: Libellulidae), and Helochares sp. (Coleoptera: Hydrophilidae). Rice fields can be important for conservation initiatives, particularly in areas where natural wetlands have declined.

\section{ACKNOWLEDGEMENTS}

This work was supported by the PMDSU Program, Directorate General of Higher Education, Ministry of Research, Technology and Higher Education of the Republic of Indonesia.

\section{REFERENCES}

Badan Pusat Statistik (BPS) Indonesia. 2019. Monthly Report on Socio Economic Data 2019. BPS RI, Jakarta.

Chazdon RL, Colwell RK, Denslow JS, Guariguata MR. 1998. Statistical methods for estimating species richness of woody regeneration in primary and second rain forest of northeastern Costa Rica, pp. 285309. In: Dallmeier F, Comoskey JA (eds) Forest Biodiversity Research, Monitoring and Modeling. Conceptual Background and Old World Case Studies. The Parthenon Publishing Group, Paris.

Cheng L, Yang CM, Andersen NM. 2001. Guide to the aquatic Heteroptera of Singapore and Peninsular Malaysia. I. Gerridae and Hermatobatidae. Raffles Bull Zool 49: 129-148.

Clausnitzer V. 2003. Dragonfly communities in coastal habitats of Kenya: Indication of biotope quality and the need of conservation measures. Biodivers Conserv 12(2): 333-356.

Colwell RK, Coddington JA. 1994. Estimating terrestrial biodiversity through extrapolation. Phylos Trans R Soc Lond B Biol Sci 345: 101118.

Corbet PS. 1980. Biology of Odonata. Ann Rev Entomol 25: 189-217.

Dunbar MJ, Warren M, Extence C, Baker L, Cadman D, Mould DJ, Hall J, Chadd R. 2010. Interaction between macroinvertebrates, discharge and physical habitat in upland rivers. Aquat Conserv 20: S31S44..DOI: 10.1002/aqc.1089.

Fenglong J, Tang YD. 2018. A revision of the Chinese Helochares (s. str.) Mulsant, 1844 (Coleoptera, Hydrophilidae). European J Taxon 438: $1-27$.

Fernando CH, Leong CY. 1963. Miscellaneous notes on the biology of Malayan Corixidae (Hemiptera: Heteroptera) and a study of the life histories of two species, Micronecta quadristrigata Bredd. and Agraptocorixa hyalinipennis (F.). J Nat Hist 69: 545-558.

Hadicke CW, Redei D, Kment P. 2017. The diversity of feeding habits recorded for water boatmen (Heteroptera: Corixoidea) world-wide with implications for evaluating information on the diet of aquatic insects. European J Entomol 114: 147-159.

Hammer O, Harper DAT, Ryan PD. 2001. PAST: paleontological statistical software package for education and data analysis. Paleontol Electron 4: 1-9.

Heong KL, Aquino GB, Barrion AT. 2009. Arthropod community structures of rice ecosystems in the Philippines. Bull Entomol Res 81: 407-416.

Hesler LS, Grigarick AA, Oraze MJ, Palrang AT. 1993. Arthopod fauna of conventional and organic rice fields in California. J Econ Entomol 86(1): 149-158.

Hidaka K. 1988. Biodiversity conservation and environmentally regenerated farming system in rice paddy fields. Jpn J Ecol 48: 167178.

Hidaka K. 1990. An approach toward a new farming system which is neither intensive nor extensive. In: Nakasuji F (eds) Insect Pest Problems in Natural and Organic Farming Systems. Okisha, Tokyo. [Japanese].

Jauharlina J, Hasnah H, Taufik MI. 2019. Diversity and community structure of arthropods on rice ecosystem. AGRIVITA J Agric Sci 41: 316-324.

Kandibane M, Raguraman S, Mahadevan NR. 2007. Diversity and community structure of aquatic arthropods in an irrigated rice ecosystem of Tamil Nadu, India. Asian J Plant Sci 6(5): 741-748.

Katayama N, Baba YG, Kusumoto Y, Tanaka K. 2014. A review of postwar changes in rice farming and biodiversity in Japan. Agric Syst 132: $73-84$.

Kiritani K. 2000. Integrated biodiversity management in paddy fields: shift of paradigm from IPM toward IBM. Integrated Pest Manag Rev 5: 175-183.

Luo Y, Fu H, Traore S. 2014. Biodiversity conservation in rice paddies in China: Toward ecological sustainability. Sustainability 6: 6107-6124.

Lutz MCG, Kehr AI, Fernandez LA. 2015. Abundance, diversity and community characterization of aquatic Coleoptera in a rice field of Northeastern Argentina. Rev Biol Trop 63: 629-638.

Magurran AE. 2004. Measuring Biological Diversity. Blackwell, Malden.

Maltchik L, Senert C, Batzer DP. 2017. Can rice field management practices contribute to the conservation of species from natural wetlands? Lesson from Brazil. Basic Appl Ecol 18: 50-56.

McPherson JE, Turner JM, Whiles MR. 2013. Diversity and community structure of stream insects in a minimally disturbed forested watershed in southern Illinois. Great Lakes Entomol 46(1-2): 42-83.

Mercer N, Kaller MD, Stout MJ. 2016. Diversity of arthropods in farmed wetlands in the Gulf of Mexico Coastal Plain and effects of detrital subsidies. J Freshwater Ecol 32(1): 163178.doi.org/10.1080/02705060.2016.1253623.

Merritt RW, Cummins KW. 1996. An Introduction to the Aquatic Insects of North America. Kendall/ Hunt Publishing Company, New York.

Molozzi J, Hepp LU, Dias AS. 2007. Influence of rice crop on the benthic community in Itajai Valley (Santa Catarina, Brazil). Acta Limnol Bras 19: 383-392.

Morse JC, Yang L, Lixin T. 1994. Aquatic Insects of China Useful for Monitoring Water Quality. Nanjing University Press, Hahai Nanjing.

Naser MN, Roy D. 2012. Feeding ecology of Chironomus larvae (Insecta: Diptera) collected from different habitat of Dhaka, Bangladesh. Bangladesh J Zool 40(1): 129-133.

Nicacio G, Juen L. 2015. Chironomids as indicators in freshwater ecosystems: an assessment of the literatures. Insect Conserv Diver 8: 393-403.

Nieser N, Chen PP, Yang CM. 2005. A new subgenus and six new species of Nepomorpha (Insecta: Heteroptera) from Yunnan, China. Raffles Bull Zool 53: 189-209.

Nieser N. 2004. Guide to aquatic Heteroptera of Singapore and peninsular Malaysia III. Pleidae and Notonectidae. Raffles Bull Zool 52: 79-96. 
Park HH, Lee JH. 2006. Arthropod trophic relationship in temperate rice ecosystem: A stable isotope analysis with $\partial^{13} \mathrm{C}$ and $\partial^{13} \mathrm{~N}$. Environ Entomol 35: 684-693.

Polhemus DA, Polhemus JT. 2013. Guide to the aquatic Heteroptera of Singapore and peninsular Malaysia. $\mathrm{x}$. infraorder Nepomorphafamilies Belostomatidae and Nepidae. Raffles Bull Zool 61: 25-45.

Ponraman G, Anbalagan S, Dinakaran S. 2016. Diversity of aquatic insects in irrigated rice fields of South India with reference to mosquitoes (Diptera: Culicidae). J Entomol Zool Stud 4(4): 252-256.

Ramirez A, Gutierrez-Fonseca PE. 2014. Functional feeding groups of aquatic insect families in Latin America: a critical analysis and review of existing literature. Rev Biol Trop 62(suppl 2): 155-167.

Rosenberg DM, Resh VH, King RS. 2008. Use of aquatic insects in biomonitoring, pp. 123-137. In: Merritt RW, Cummins KW (eds) An Introduction to the Aquatic Insects of North America ( $\left.4^{\text {th }} \mathrm{ed}\right)$. Kendall Hunt Publishing Company, Iowa.

Salmah MRC, Siregar AZ, Hassan AA, Nasution Z. 2017. Dynamics of aquatic organisms in a rice field ecosystem: effects of seasons and cultivation phases on abundance and predator-prey interactions. Trop Ecol 58: 177-191.

Savage AA. 1989. Adults of the British Aquatic Hemiptera Heteroptera. A key with ecological notes. Sci Publ Freshw Biol Assoc 50: 1-173.

Schoenly KG, Hilario D, Justo J, Barrion AT, Harris MK, Bottrell AG 1998. Analysis of invertebrate biodiversity in a Philippine farmer's irrigated rice field. Environ Entomol 27: 1125-1136.

Settele J, Spangenberg JH, Heong KL, Kühn I, Klotz S, Arida G, Burkhard B, Bustamante JV, Cabbigat J, Canh LX. 2019. Rice Ecosystem Services in South-East Asia: The LEGATO Project, Its Approaches and Main Results with a Focus on Biocontrol Services. 373-382.

Settle WH, Ariawan H, Astuti ET, Cahyana W, Hakim AL, Hindayana D, Lestari AS. 1996. Managing tropical rice pests through conservation of generalist natural enemies and alternative prey. Ecology 77: 19751988.

Stenert C, de Melo ICMF, Pires MM, Knauth DS, Katayama N, Maltchik L. 2018. Responses of macroinvertebrate communities to pesticide application in irrigated rice fields. Environ Monit Assess 190(74): 1 13

Stenert C, Maltchik L, Rocha O. 2012. Diversity of aquatic invertebrates in rice fields in southern Brazil. Neotrop Biol Conserv 7: 67-77.

Thongphak D, Iwai CB. 2016. Diversity of aquatic insects in the organic and conventional rice fields in Khon Kaen Thailand. Int J Environ Rural Develop 7: 57-62.

Tokeshi M. 1995. Production Ecology, pp. 269-296. In Armitage PD, Cranston PS, Pinder LCV (eds.). The Chironomidae: biology and ecology of non-biting midges. Chapman \& Hall, London. 584 p.

Ueno T. 2012. Insect natural enemies as bioindicators in rice paddies. Korean J Agric Sci 39: 545-553.

Wandscheer ACD, Marchesan E, Santos S, Zanella R, Silva MF, Londero GP, Donato G. 2017. Richness and density of aquatic benthic macroinvertebrates after exposure in fungicides and insecticides in rice paddy fields. Ann Acad Braz Sci 89(1): 355-369.

Way MJ, Heong KL. 1994. The role of biodiversity in the dynamics and management of insect pests of tropical irrigated rice-a review. Bull Entomol Res 84: 567-587.

Wilson AL, Watts RJ, Stevens MM. 2007. Effects of different management regimes on aquatic macroinvertebrate diversity in Australian rice fields. Ecol Res 23: 565-572.

Yang CM, Zettel H. 2005. Guide to the aquatic Heteroptera of Singapore and peninsular Malaysia. V. Hydrometridae. Raffles Bull Zool 53: 7997.

Yano K, Miyamoto S, Gabriel BP. 1981. Faunal and biological studies on the insects of paddy fields in Asia. iv. aquatic and semiaquatic Heteroptera from the Philippine. ESAKIA 16: 5-32.

Yano K, Yau-I-Chu, Resma P, Sato M. 1983. Faunal and biological studies on the insects of paddy field in Asia. XII. Aquatic coleopteran from Taiwan and the Philippines. Chinese J Entomol 3: 103-118.

Zhang J, Zheng X, Jian H, Qin X, Yuan F, Zhang R. 2013. Arthropod biodiversity and community structures of organic rice ecosystems in Guangdong Province, China. Florida Entomol 96: 1-9. 